\title{
BIOGEOGRAPHIC AND SPECIES RICHNESS PATTERNS OF GASTROPODA ON THE SOUTHWESTERN ATLANTIC
}

\author{
FLOETER, S. R. ${ }^{1}$ and SOARES-GOMES, A. ${ }^{2}$ \\ ${ }^{1}$ Departamento de Ecologia e Recursos Naturais, Universidade Federal do Espírito Santo, \\ Av. Fernando Ferrari S/N, CEP 29060-900, Vitória, ES, Brazil \\ ${ }^{2}$ Programa de Pós-Graduação em Biologia Marinha, Universidade Federal Fluminense, C.P. 100.644, \\ CEP 24001-970, Niterói, RJ, Brazil \\ Correspondence to: Sergio R. Floeter, Cond. Village, Ed. Degas, 204, Ilha do Boi, CEP 29052-730, Vitória, ES, \\ Brazil, e-mail: floeter.vix@zaz..com.br \\ Received September 10, 1998 - Accepted November 17, 1998 - Distributed December 22, 1999
}

(With 4 figures)

\begin{abstract}
Patterns of richness and biogeography of Gastropoda molluscs were determined based on lists of species from five sites along the southwestern Atlantic. The analysis of the distribution patterns of these sites confirmed the existence of a broader transition zone between southern Espírito Santo State $\left(21^{\circ} \mathrm{S}\right)$ and Rio Grande do Sul State $\left(32^{\circ} \mathrm{S}\right)$. This zone is very heterogeneous, presenting a low endemism rate and a significant number of species common to the near provinces, and does not show enough consistency to be considered as an independent biogeographic province as proposed by Palacio (1980). Observing the distribution of species along the southwestern Atlantic we find an increase in the proportion of species with greatest latitudinal ranges (occurring from the tropics to Patagonia) from lowest to highest latitudes, following Rappoport's rule.
\end{abstract}

Key words: biogeography, Gastropoda, southwestern Atlantic, diversity.

\section{RESUMO}

\section{Biogeografia de gastrópodes no Atlântico Sul ocidental}

Padrões de riqueza e biogeografia de moluscos Gastropoda foram determinados baseados em listas de espécies de cinco locais ao longo do Atlântico Sul ocidental. A análise dos padrões de distribuição destes confirmou a existência de uma ampla zona de transição entre o sul do Estado do Espírito Santo $\left(21^{\circ} \mathrm{S}\right)$ e o Estado do Rio Grande do Sul $\left(32^{\circ} \mathrm{S}\right)$. Essa zona é muito heterogênea e apresenta baixa taxa de endemismo e um número significante de espécies comums às províncias mais próximas, não demonstrando consistência para ser considerada uma província biogeográfica independente, como proposto por Palacio (1980). Observando a distribuição das espécies ao longo do Atlântico Sul ocidental, foi encontrado um aumento da proporção de espécies com maiores amplitudes latitudinais (que ocorrem desde regiões tropicais até a Patagônia), de baixas latitudes para latitudes mais altas, seguindo a Regra de Rappoport.

Palavras-chave: biogeografia, Gastropoda, Atlântico Sul ocidental, diversidade, riqueza.

\section{INTRODUCTION}

The spatial arrangement of the continents and oceans, combined with the influence of temperature and latitudinal gradients, local circulation patterns, and water properties divide the oceans into a series of provinces, or biogeographic regions with characteristic assemblages. Boundaries between provinces can be water mass borders, major thermal or salinity discontinuities (Levinton, 1995). 
Using zoogeographic provinces defined by Palacio (1980), The Paulista Province is considered a broad transition zone between warm and cold water species and a north-south gradient defining the gradual disappearance of the tropical fauna and the beginning of the Patagonian species. Several authors agree with this broad transition zone (Dana, 1853 apud Palacio, op. cit., Carcelles, 1944; Boltovskoy, 1964; Stuardo, 1964; Coelho \& Santos, 1980; Tommasi, 1985).

Some authors claim that Cabo Frio is the limit between the Tropical Province and the Temperate or Patagonian Province (Ekman, 1953; Briggs, 1974); others think that it is a transition zone that starts at the Cabo Frio region, acting as an important ecological "filter" for the temperate species (Vannucci, 1964; Absalão, 1989) and continues to southern Brazil. However, these authors did not recognize Cabo Frio as a provincial zone, only as a transition region (Melo, 1985; Absalão, 1989).

The aim of this work was to compare the species distribution of gastropods at various sites along the Caribbean and Brazilian coast. Studies of this nature can be a valuable tool for a better understanding of the southwestern Atlantic marine biodiversity and biogeography.

\section{MATERIAL AND METHODS}

Data were drawn from five lists of Gastropoda species - Margarita Shelf - Venezuela (1054'N) (Carvajal \& Capelo, 1993); Marataízes ES (2110'S) (Floeter, 1996); Campos Basin - RJ (22 $30^{\circ}$ 'S) (Miyaji, 1995); Ubatuba - SP (2330'S) (Pires-Vanin, 1989); Rio Grande - RS (3200'S) (Absalão, 1986) - and were classified into five patterns of geographic distribution according to Palacio (1980), considering the northern limit of the Tropical Province as Cape Hatteras $\left(35^{\circ} 15^{\prime} \mathrm{N}\right)$ (Carcelles, 1944).

\section{RESULTS AND DISCUSSION}

\section{Biogeographic considerations}

The water temperature is thought to be the principal limiting factor of the majority of shallow water species (Stuardo, 1964; Hall, 1964; Vannucci, 1964; Barnes \& Hughes, 1988; Levinton, 1995), and it has been the basis of all discussion about the provincial limits in the southwestern Atlantic
(Ekman, 1953; Boltovskoy, 1964; Stuardo, 1964; Vannucci op. cit.; Semenov, 1978; Coelho \& Santos, 1980; Palacio, 1980; Absalão, 1989).

Ekman (1953) and Hall (1964) defined tropical region using $20^{\circ} \mathrm{C}$ and $18^{\circ} \mathrm{C}$ as minimal temperatures reached during the coldest months of the year. On the other hand, Hall (1964), working exclusively with molluscs, determined the marine shallow water climates by the number of consecutive days or months that shallow sea water is at required temperatures for reproduction and early growth. The Tropical Province, for example, is defined by the group of species that live at $20^{\circ} \mathrm{C}$ water temperature for six or more months, with no months cooler than $18^{\circ} \mathrm{C}$.

According to Carcelles (1944), concerning the mollusc distribution, the Tropical (or Caribbean) Province has its northern limit at Cape Hatteras $\left(35^{\circ} 15^{\prime} \mathrm{N}\right)$ and a southern limit at Cape Santa Marta Grande (28 28'S). Ekman (1953), based on reef formations and water temperature of $20^{\circ} \mathrm{C}$ in the coldest months, suggests the Rio de Janeiro region as the limit between the temperate and tropical faunas. Vannucci (1964) points out that mangroves should be used as indicators of the tropical fauna limit. There is no doubt that the Cabo Frio latitude $23^{\circ} \mathrm{S}$ represents the northern and southern boundary for many species, but the existence of mangrove swamps as far south as Santa Catarina, as well as a considerable number of species belonging to the Caribbean fauna, show that this limit is much broader than Ekman (op. cit.) and others had suggested.

Cabo Frio is suggested by Briggs (1974) to be the limit between the Brazilian and the Patagonian Provinces using 10\% of endemism as the criteria for province definition. Briggs (op. cit.), consider the Brazilian Province as the region from the Orinoco River to Cabo Frio.

Palacio (1980), in his southwestern Atlantic zoogeographical review, do not recognize the Brazilian Province as a valid province and proposed the establishment of a zoogeographic province, the Paulista Province, based in many studies of the fauna, flora, oceanic circulation patterns, morphology, and geology of the Brazilian coast. This province would have as its northern limit the $23^{\circ} \mathrm{C}$ isotherm between southern Espírito Santo and Northern Rio de Janeiro, and the Southern boundary between Rio Grande do Sul 
and Uruguay (Fig. 1). This zone is characterized by having a significant portion of endemic elements, and some adjacent fauna members constituting a broad transition zone between tropical and temperate water species, having the gradual disappearance of the tropical fauna and the beginning of the patagonic fauna based on a north-south gradient. The distribution of the gastropods provides some insights for a better comprehension the southwestern Atlantic zoogeographical patterns.

The geographic distribution patterns of the gastropods species from the Margarita Shelf $\left(10^{\circ} 54^{\prime} \mathrm{N}\right)$, in the Venezuelan Caribbean (Carvajal \& Capelo, 1993), showed a great majority of species belonging exclusively to the Tropical Province $(65.3 \%)$, with a considerable amount of species common to the Tropical and Paulista Provinces $(31.9 \%)$, and a very low number for the Tropical, Paulista, and Patagonic Provinces (2.7\%) (Fig. 2).

In the Marataízes region $\left(21^{\circ} 10^{\prime} \mathrm{S}\right)$ (Floeter, 1996), the great proportion of tropical species as well as the new occurrences of warm water species found, reinforce the affinity between the malacofauna of the region with tropical waters, demonstrating the importance of the Brazilian Current in the maintenance of this biogeographic structure (Absalão, 1989) (Fig. 2). Marataízes is on the boundary between the Tropical Province and the Paulista Province. This region is almost entirely covered with wide shallow $(10-25 \mathrm{~m})$ calcareous algal banks, mainly of the family Corallinaceae. These extensive banks create various microhabitats of great structural and ecological complexity, similar to coral reefs. In fact, this benthic community is characterized by a high specific richness, a great variety of taxonomic groups, and many biological forms (Hong, 1982; Barnes \& Hughes, 1988).

A substantial difference, however, was found between the proportion of species common to both tropical and Paulista regions when we compare the Marataízes region $-21^{\circ} 10^{\prime} \mathrm{S}(64.9 \%)$ and Margarita Shelf $-10^{\circ} 40^{\prime} \mathrm{N}$ in the Venezuelan Caribbean (31.9\%). In addition, the fact that Marataízes represents the southern limit for many species (22.1\% of the total), suggests that the Marataízes region is located at the beginning of a transition zone. Young (1995) working with barnacle distribution patterns, also defines the beginning of subtropical zone on latitude $21^{\circ} \mathrm{S}$.

In Ubatuba (2330'S) (Pires-Vanin, 1989), there is an important increase in the species percentages with cold water affinities - belonging to the Paulista and Patagonic Provinces - (43.2\%) compared to Marataízes $(2.3 \%)$ and Campos Basin - 22³0’S - (15.3\%) (Miyaji, 1995); Nevertheless, there is still an important contribution of warm water species (16.2\%) (Fig. 2).

In Rio Grande $\left(32^{\circ} \mathrm{S}\right)$ on the southern boundary of the Paulista Province, temperate water species constitutes the great majority of the species (69.2\%) (Absalão, 1986), showing not only an impressive latitudinal gradient in relation with Ubatuba, but also characterizing the Paulista Province as a transitional zone (Fig. 2). The circulation in Rio Grande shows a clear seasonal pattern, in which the interaction between the wind driven transport and geostrophic circulation over the shelf produce a net flow directed southward and offshore during summer - warm waters, and northward and onshore during winter - SubAntarctic waters (Lima et al., 1996).

The Cabo Frio region $\left(23^{\circ} \mathrm{S}\right)$ does not seem to be a great natural barrier. Neves (1994), studying the Rio de Janeiro continental shelf micromolluscs, did not find remarkable differences between the northern and southern fauna of this region.

Cabo Frio itself is specially permeable to tropical species, having on the southern coast of Rio de Janeiro, $40.2 \%$ of species common to this fauna (Absalão, 1989) and also in Santos, SP, Vannucci (1964) found the same value. Although it functions as an ecological "filter" quite impermeable to patagonic species (Vannucci, op. cit.; Absalão, op. cit.; Mello, 1993).

Another important characteristic of the Cabo Frio area is the gradual disappearance of the calcareous bottom, due to the increase of terrigenous sediments in the South of this region (Mabesoone, 1971; Kempf, 1972).

As a result, the distribution of tropical species, related to calcareous beds would have its southern limit at Cabo Frio, not directly related to climatic zones, which traditionally limits the faunal provinces (Miyaji, 1995). This fact helps to explain the decrease of the species richness below Cabo Frio $\left(23^{\circ} \mathrm{S}\right)$ (see Table 1$)$, since calcareous banks are highly diverse environments. 


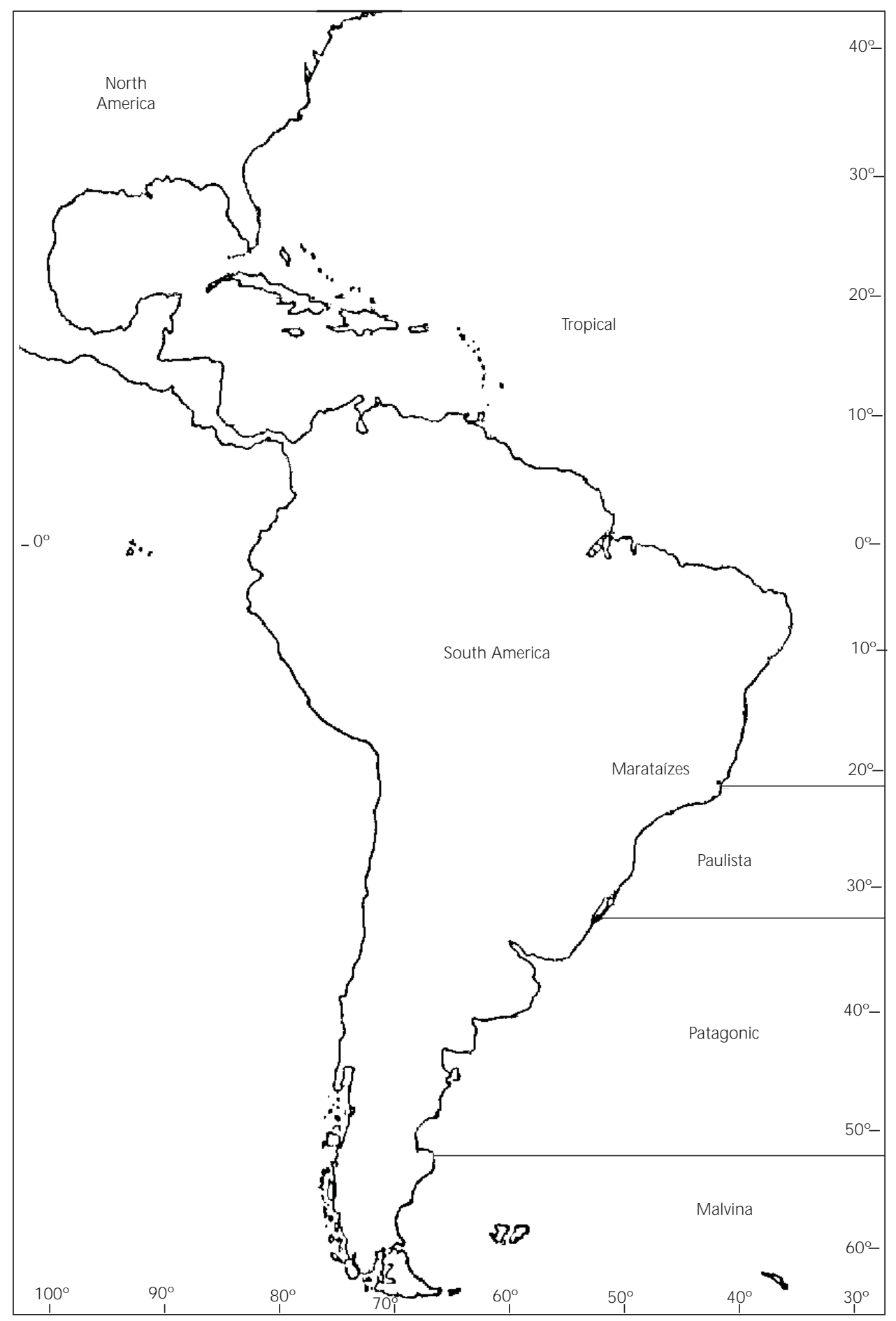

Fig. 1 - Southwestern Atlantic zoogeographical Provinces according to Palacio (1980). 


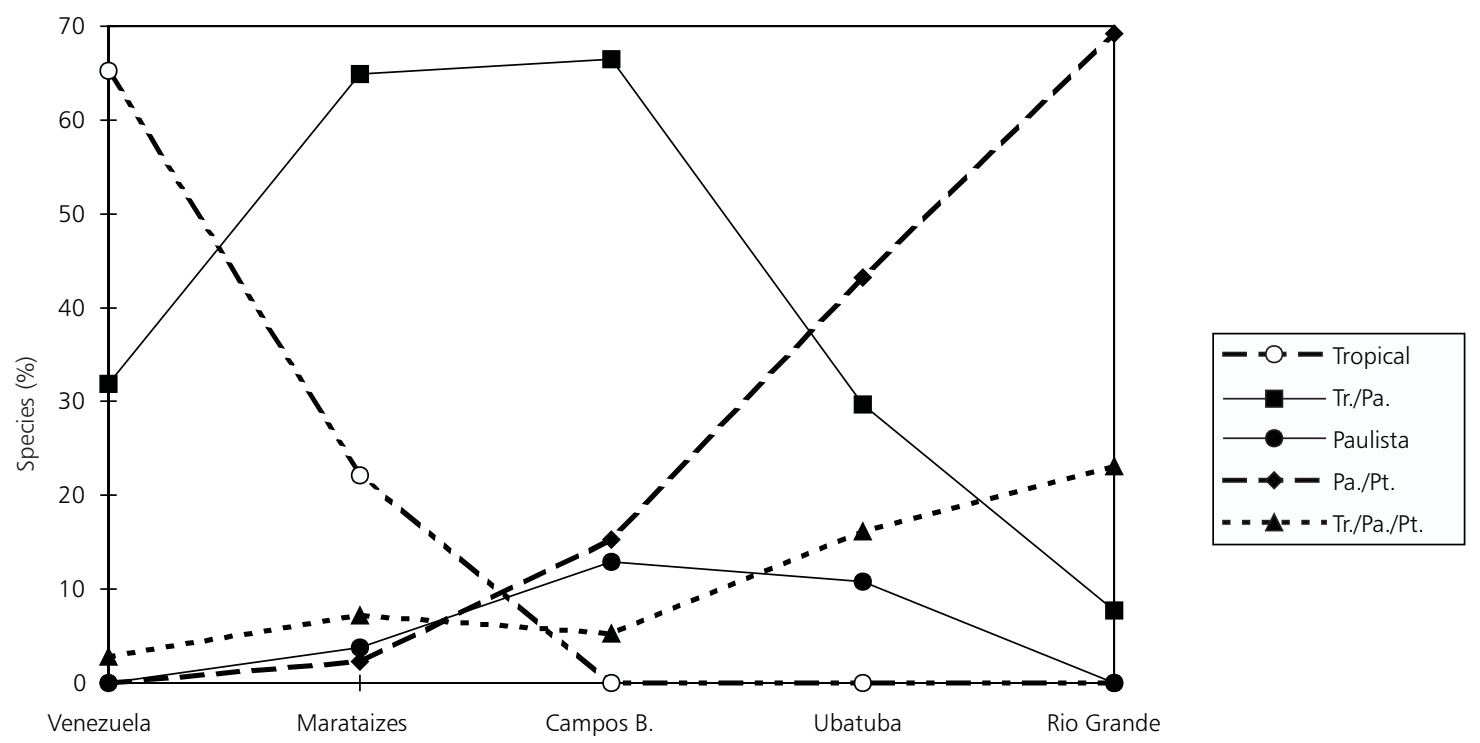

Fig. 2 - Geographic distribution pattern of Gastropoda: Margarita Shelf - Venezuela (1054’N) (Carvajal \& Capelo, 1993);

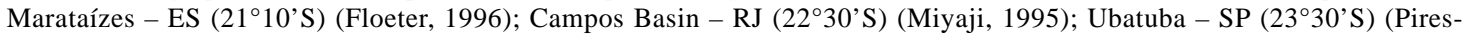
Vanin, 1989); Rio Grande - RS (3200’S) (Absalão, 1986).

The endemism rate of some distinctive groups: Gastropods - in the Campos Basin $\left(22^{\circ} 30^{\prime} \mathrm{S}\right)$ and in Ubatuba $\left(23^{\circ} 30^{\prime} \mathrm{S}\right)$, the endemic species of constitute respectively $12.9 \%$ (Miyaji, 1995 ) and $10.8 \%$ (Pires-Vanin, 1989). Errant polychaetes - the data provided by Lana (1987) and Paiva (1990 apud Miyaji, 1995) shows a high endemism rate (27\%) for the of Paraná State coast. Reef fishes - there is a steadily growing evidence that a sizable portion of the Brazilian reef ichthyofauna is endemic to the western South Atlantic and many supposedly Caribbean reef fish species recorded for the Brazilian coast proved later to be undescribed endemic species (Moura et al., 1999) - supply elements for the establishment of the Paulista Province, as proposed by Palacio (1980). Additional taxonomic studies on the referred groups will be required to clarify some of these issues.

However, great differences between different places within the Paulista Province (Fig. 2), and the large proportion of species occurring from the tropical to patagonic regions (16.2\% in Ubatuba, and $23.1 \%$ in Rio Grande) show the transitional character of the region (Fig. 4), as well as its biogeographic heterogeneity, agreeing with Stuardo (1964), Vannucci (1964), and Tommasi (1985).
Moreover, the low overall molluscan endemism rate found by Palacio (1980) (4.27\% exclusive of the supposed Paulista Province), and Rios (1994) in his extensive work $(5.14 \%$ of endemism for Gastropoda), did not show sufficient consistency (at least in terms of molluscs) to support the individualization of this region as a biogeographic unit (Absalão, 1989; Melo, 1985).

\section{Richness Patterns}

The species richness tends to increase with decreasing latitude. It is common knowledge that the tropics are richer in life than colder regions (Ekman, 1953; Barnes \& Hughes, 1988; Stevens, 1989; Levinton, 1995).

The best known richness gradient is the increase from high to low latitudes in continental shelf benthos (Levinton, op. cit.). The prosobranch gastropods, for example, show a strong latitudinal decrease in species richness from tropical regions, where primary production is continuous throughout the year, to the colder regions where this production shows seasonal pulses (Barnes \& Hughes, op. cit.).

In the Brazilian coast there is a latitudinal decrease in the number of coral (Leão et al., 1988) and reef fish species (Moura et al., 1999). 
TABLE 1

Gastropoda richness data on the western Atlantic.

\begin{tabular}{|c|c|c|c|c|}
\hline$n^{0}$ of spp. & Habitat/site: & $\begin{array}{l}\text { Latitude: } \\
\text { (aprox.) }\end{array}$ & $\begin{array}{c}\text { Sampler/period/ } \\
\text { obs. }\end{array}$ & References: \\
\hline 24 & $\begin{array}{c}\text { Port/estuary } \\
\text { Hampton Roads, USA }\end{array}$ & $37^{\circ} 20^{\prime} \mathrm{N}$ & Petersen grab & Boesch, 1973 \\
\hline 39 & $\begin{array}{l}\text { Continental Shelf } \\
10 \text { e } 50 \mathrm{~m} \\
\text { Rio Grande, RS }\end{array}$ & $32^{\circ} 00^{\prime} \mathrm{S}$ & $\begin{array}{l}\text { Picard's dredge } \\
44 \text { stations }\end{array}$ & Absalão, 1986 \\
\hline 56 & $\begin{array}{c}\text { Continental Shelf } \\
100 \mathrm{~m} \\
\text { RJ, Brazil }\end{array}$ & $23^{\circ} 00^{\prime} \mathrm{S}$ & $\begin{array}{l}\text { van Veen grab } \\
65 \text { stations }\end{array}$ & Absalão, 1986 \\
\hline 130 & $\begin{array}{c}\text { Continental Shelf } \\
\text { Southern Espírito Santo } \\
\text { Brazil }\end{array}$ & $21^{\circ} 30^{\prime} \mathrm{S}$ & Dredge & Absalão, 1989 \\
\hline 161 & $\begin{array}{l}\text { Continental Shelf } \\
15-18 \mathrm{~m} \\
\text { Marataízes, ES }\end{array}$ & $21^{\circ} 10^{\prime} \mathrm{S}$ & $\begin{array}{c}\text { Hand corer (SCUBA) } \\
9 \text { stations }\end{array}$ & Floeter, 1996 \\
\hline 173 & $\begin{array}{l}\text { Continental Shelf } \\
\text { Cabo Frio, RJ } \\
\text { region }\end{array}$ & $23^{\circ} 00^{\prime} \mathrm{S}$ & $\begin{array}{c}\text { Dredge } \\
59 \text { stations }\end{array}$ & Neves, 1994 \\
\hline 254 & $\begin{array}{l}\text { Continental Shelf } \\
\text { 10-100 m } \\
\text { Campos Basin, RJ }\end{array}$ & $22^{\circ} 30^{\prime} \mathrm{S}$ & $\begin{array}{c}\text { van Veen, dredges and } \\
\text { trawl } \\
2 \text { years }\end{array}$ & Miyaji, 1995 \\
\hline 485 & $\begin{array}{l}\text { Parque Natural Tayrona } \\
\text { 0-200 m } \\
\text { Colombian Caribbean }\end{array}$ & $11^{\circ} 17^{\prime} \mathrm{N}$ & $\begin{array}{c}\text { Trawl with "Agassiz" net } \\
\text { van -Veen, dredge } \\
\text { and SCUBA }\end{array}$ & Diaz, 1994 \\
\hline 745 & $\begin{array}{c}\text { Curaçao, Aruba \& } \\
\text { Bonaire }\end{array}$ & $12^{\circ} 15^{\prime} \mathrm{N}$ & $\begin{array}{c}\text { A long term } \\
\text { compilation work }\end{array}$ & $\begin{array}{c}\text { Jong \& } \\
\text { Coomans, } 1988\end{array}$ \\
\hline
\end{tabular}

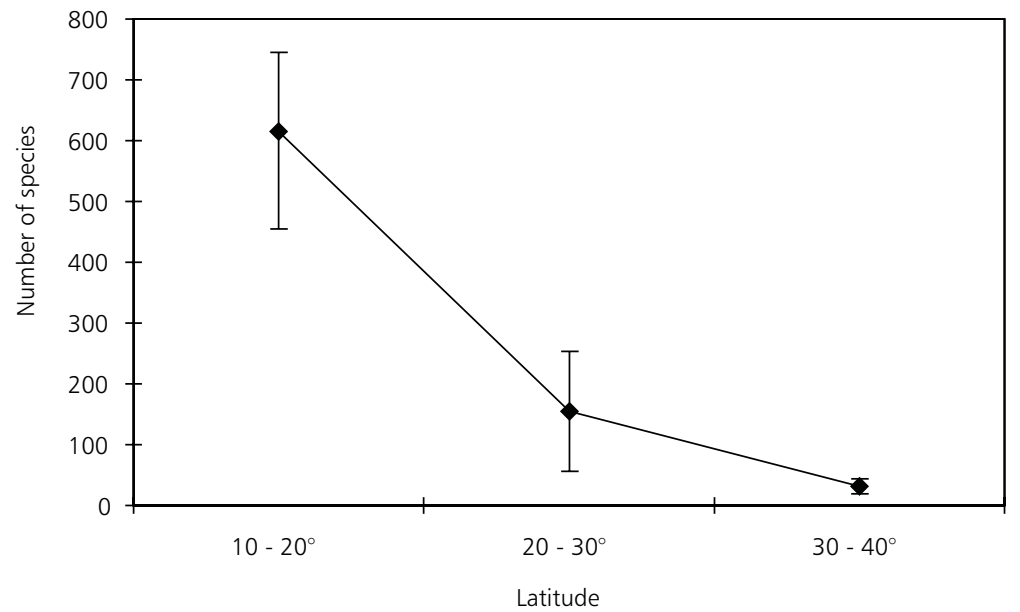

Fig. 3 - Species richness gradient (max., min., and average) along the western Atlantic (values from Table 1). 


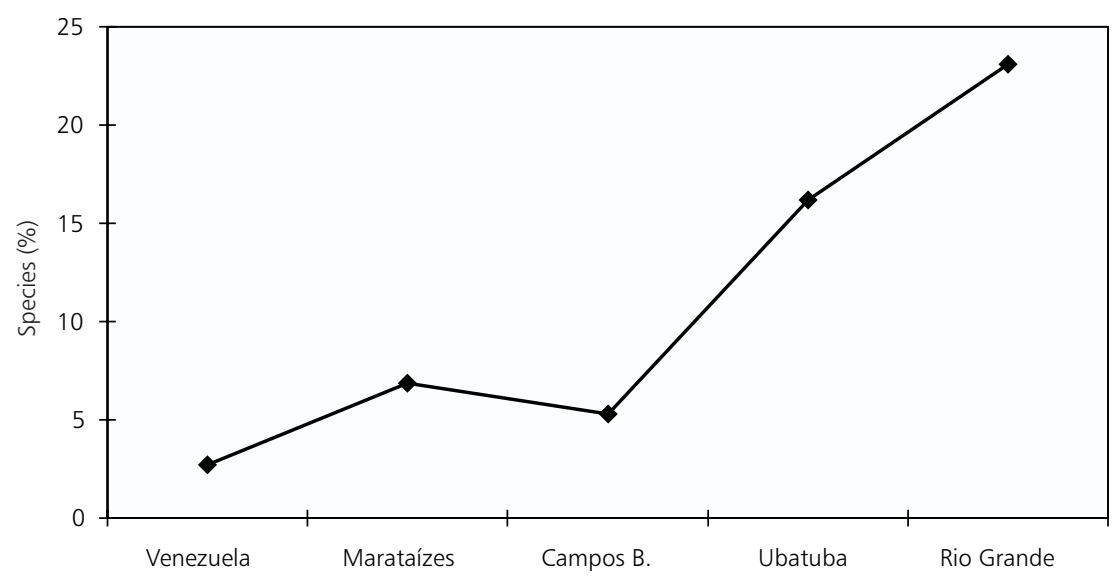

Fig. 4 - Gradient of species with wide geographic extent (occurring from the tropics to Patagonia) along the southwest-

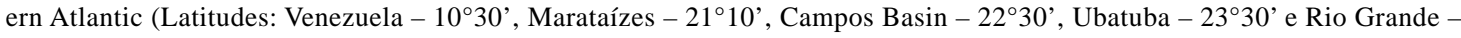
$\left.32^{\circ} 00^{\prime}\right)$.

The most commonly proposed factors responsible for this global pattern are: greater habitat diversity (environmental heterogeneity) in the tropics, the trophic stability, the continuous primary production and the diversity associated with complex three-dimensional architecture (of coral reefs or algae beds at low latitudes), the impact of predation in maintaining diversity and a greater physical oceanographic stability. This pattern is found when we plot the gastropod richness results obtained in works done along the western Atlantic (Fig. 3 and Table 1). Although different collecting methods were used (the comparison in Table 1 should be done very carefully, due to methodological problems such as: standardization of the sampling methods, mesh size, replication, and the great variety of size and depth in the sampling areas) the general trend is clear.

Observing the distribution of species along the southwestern Atlantic (Fig. 4), we find another interesting pattern: an increase of the proportion of species with greater latitudinal ranges (occurring from the tropics to Patagonia) from lower to higher latitudes. The proportion in Campos Basin were similar to Marataízes resulting in a slight deviation from the general trend.

Recently, Stevens (1989) proposed that there is an inversely proportional ecological connection between the correlation of geographical-range size and latitude (Fig. 4) and the correlation between species richness and latitude (Fig. 3). This is a phenomenon Stevens called Rappoport's rule. According to Stevens (op. cit.) this rule suggests that tropical organisms have narrower environmental tolerances than temperate or polar organisms.

The broad tolerance of individuals from high latitudes has lead to wider latitudinal extent in the geographical range of high-latitude species than of lower-latitude species. Although our results followed this pattern, there are many authors that do not agree with it.

Rohde (1996) and Rohde \& Heap (1996) have shown that there are always exceptions to this correlation and that tropical animals have not been shown to have consistently narrower latitudinal ranges from higher latitudes. Thus, it cannot explain latitudinal gradients in species diversity.

Colwell \& Hurtt (1994) have shown that a spurious Rappoport effect can be the result of a sampling bias, arising from a decline in the perspecies sampling effort in high-diversity regions, even when the total sampling effort is equal.

Hopefully, the present study on gastropods biogeography will stimulate further interest and research in this area.

Acknowledgments - We would like to thank Paulo Márcio Costa, Ricardo Absalão, Brian Canas, Cíntia Myaji, Paulo Y. G. Sumida, Rosebel C. Nalesso and Samuel Snedaker for the helpful comments and revision; Gilberto Dias and Fabio B. Pitombo for helping in the samplings. This research was supported by a CNPq grant (№ 120907/95-0). 


\section{REFERENCES}

ABSALÃO, R. S., 1986, Discriminação Ambiental entre Associações de Moluscos Macro-Bentônicos ao Largo de Rio Grande, RS, Brasil. Situação Inverno-Primavera. MSc. Thesis. Universidade do Rio Grande, RS, $120 \mathrm{p}$.

ABSALÃO, R. S., 1989, Padrões distributivos e zoogeografia dos moluscos da plataforma continental brasileira. Parte III. Comissão oceanográfica Espírito Santo I. Rio de Janeiro, Mem. Inst. Oswaldo Cruz, 84(4): 1-6.

ABSALÃO, R. S. \& CRUZ, R. L., 1990, Moluscos da plataforma continental brasileira. Parte II: comissão oceanográfica "Geomar X". São Paulo, Naturalia, 15: 21-33.

ABSALÃO, R. S. \& RIOS, E. C., 1995, Descriptions of two new species of Caelatura (Gastropoda, Rissoidea, Barleeidae) from Brazil. Apex, 10(2-3): 87-93.

BARNES, R. S. K. \& HUGHES, R., 1988, Speciation and Biogeography (Cap. 10). In: An Introduction to Marine Ecology, 2nd Edition, Oxford, Blackwell Scientific Publications. $351 \mathrm{p}$.

BRIGGS, J. C., 1974, Marine Zoogeography. New York, McGraw-Hill (Publishers), 475p.

BOESCH, D. F., 1973, Classification and community structure of macrobenthos in Hampton Roads area, Virginia, U.S.A. Mar. Biol., 21: 226-244.

BOLTOVSKOY, E., 1964, Provincias zoogeográficas de América del Sur y su sector Antártico según los foraminíferos bentónicos. Bol. Inst. Biol., Mar., 7: 93-99.

CARCELLES, A., 1944, Catálogo de los moluscos marinos de Puerto Quequén. Revista Mus. La Plata (N.S.) Zool., 3: 233-309.

CARVAJAL, F. \& CAPELO, J., 1993, Los moluscos de la plataforma Margarita-Coche-Tierra firme (Venezuela), su distribuición y abundancia. Mem. Soc. Cien. Nat. La Salle., 140: 159-175.

COELHO, P. A. \& SANTOS, M. F., 1980, Zoogeografia marinha do Brasil. I. Considerações gerais sobre o método e aplicação a um grupo de crustáceos (Paguros: Crustácea Decápoda, super-famílias Paguroidea e Coenobitoidea). Bol. Inst. Oceanogr. S. Paulo, 29(2): 139-144.

COLWELL, R. K. \& HURTT, G. C., 1994, Nonbiological gradients in species richness and a spurious Rapoport effect. Am. Nat., 144: 570-595.

DÍAZ, J. M., 1994, La malacofauna de la zona costera de Santa Marta y Parque Nacional Natural Tayrona, Caribe Colonbiano. An. Inst. Invest. Mar. Punta Betín, 23: 15-43.

EKMAN, S., 1953, Zoogeography of the Sea. London, Sidgwick \& Jackson (Publishers), 417p.

FLOETER, S. R., 1996, Padrões de Biogeografia e Riqueza de Espécies de Gastrópodes da Região de Marataízes, ES. Considerações para o Atlântico Sul Ocidental. PostGraduation Thesis, Universidade Federal Fluminense Instituto de Biologia, 42p.

HALL Jr., C., A., 1964, Shallow water marine climates and molluscan provinces. Ecology, 45(2): 226-234.
HONG, J. S., 1982, Contribution à l'étude des peuplements d'un fond de Concrétionnement Coralligène dans la région marseillaise en Méditerranée Nord-Occidentale. Bull. of KORDI, 4: 27-51.

KEMPF, M., 1972, A plataforma continental da costa leste brasileira, entre o Rio São Francisco e a Ilha de São Sebastião $\left(10^{\circ} 30^{\prime}-25^{\circ}\right.$ lat $\left.S\right)$ : Notas sobre os principais tipos de fundo. In: Anais do XXVI Congresso Brasileiro de Geologia, São Paulo, 2: 211-234.

LANA, P. C., 1987, Padrões de distribuição dos poliquetas errantes (Annelida: Polychaeta) do Estado do Paraná. Ciência Cult., S. Paulo, 39(11): 1060-1063.

LEÃO, Z. M. A., Araújo, T. M. F. \& Nolasco, M. C., 1988, The coral reefs off the coast of eastern Brazil. Proc. 6th Int. Coral Reef Symp, pp. 339-347.

LEVINTON, J. S., 1995, Biotic Diversity in the Ocean. In: Marine Biology. Function, Biodiversity, Ecology, New York, Oxford University Press, 420p.

LIMA, I. D., Garcia, C. A. E. \& Möller, O. O., 1996, Ocean surface processes on the southern Brazilian shelf: characterization and seasonal variability. Contin. Shelf Res., 16(10): 1307-1317.

MABESOONE, J. M., 1971, Bacias sedimentares da Plataforma Continental Brasileira. Est. Sedimen., 1(1): 55-71.

MELO, G. A. S., 1985, Taxonomia e Padrões Distribucionais e Ecológicos dos Brachyura (Crustacea: Decapoda) do Litoral Sudeste do Brasil. PhD. Thesis, Instituto de Biociências, Universidade de São Paulo, 215p.

MELLO, R. L. S., 1993, Moluscos do Brasil. I. Gastropoda, Bivalvia e Scaphopoda, coletados durante as viagens do navio oceanográfico "Almirante Saldanha". Comissão Sul I. Considerações biogeográficas. Bol. Museu Malacol., Recife, 1: 31-49.

MIYAJI, C., 1995, Composição e Distribuição da Fauna de Moluscos Gastrópodes e Bivalves da Plataforma Continental da Região da Bacia de Campos (Rio de Janeiro, Brasil). MSc. Thesis, Instituto Oceanográfico, Universidade de São Paulo, 134p.

MOURA, R. L., GASPARINI, J. L. \& SAZIMA, I., 1999, New records and range extentions of reef fishes in the western South Atlantic, with comments on reef fish distribution along the Brazilian coast. Rev. Bras. Zool., 16(2): 513-530.

NEVES, E. G., 1994, Padrões de Distribuição Zoogeográfica dos Micromoluscos da Plataforma Continental do Estado do Rio de Janeiro, Comissão Oceanográfica Cabo Frio VII. Bachelor Thesis, Depto. de Biologia Marinha, Universidade Federal do Rio de Janeiro, 80p.

PALACIO, F. J., 1980, Revisión zoogeográfica marina del sur del Brasil. Bol. Inst. Oceanogr., São Paulo, 31(1): 69-92.

PIRES-VANIN, A. M., 1989, Estrutura e dinâmica da megafauna bêntica na plataforma continental da região norte do estado de São Paulo, Brasil. Tese de LivreDocência, Instituto Oceanográfico, Universidade de São Paulo, 172p.

RIOS, E. C., 1994, Seashells of Brazil (2nd Edition). Rio Grande, Museu Oceanográfico da Fundação Universidade de Rio Grande, 331p. + 102 plates. 
ROHDE, K., 1996, Rapoport's Rule is a local phenomenon and cannot explain latitudinal gradients in species diversity. Biodiv. Letters, 3: 10-13.

ROHDE, K. \& HEAP, M., 1996, Latitudinal ranges of teleosts fish in the Atlantic and Indo-Pacific oceans. Am. Nat., 147: 659-665.

SEMENOV, V. N., 1978, Geographical distribution of benthos on the south american shelf as a function of the distribution of coastal waters. Oceanology, 18(1): 77-87.

STEVENS, G. C., 1989, The latitudinal gradient in geographical range: How so many species coexist in the tropics. Am. Nat., 133: 240-256.
STUARDO, J. B., 1964, Distribuición de los moluscos marinos litorales en latinoamerica. Bol. Inst. Biol. Mar., 7: 79-91.

TOMMASI, L. R., 1985, Equinodermas da região da Ilha da Vitória, SP. Rel. Int. Inst. Oceanogr., Univ., S. Paulo, 13: $1-5$.

VANNUCCI, M., 1964, Zoogeografia marinha do Brasil. Bol. Inst. Biol., Mar., 7: 113-121.

YOUNG, P. S., 1995, New interpretations of South American Patterns of barnacle distribution. In: Crustacean Issues 10, - New Frontiers in Barnacle Evolution. Rotterdam, Schram \& Hoeg (Publishers), 229p. 